\title{
PERITRAUMATIC FACTORS AND POSTTRAUMATIC SYMPTOMS IN CHILD SEXUAL ABUSE CASES
}

\author{
Raitis Eglītis ${ }^{1,2}$, Dace Landmane ${ }^{3}$ \\ ${ }^{1}$ University of Latvia, Faculty of Pedagogy, Psychology and Art, ${ }^{2}$ Riga Centre of Psychiatry and \\ Addiction Disorders, ${ }^{3}$ Central Criminal police department of Latvia
}

Key words: child sexual abuse, trauma, peritraumatic distress, peritraumatic dissociation, posttraumatic reactions.

\begin{abstract}
Summary
Health and legal professionals are aware of adverse effects child sexual abuse (CSA) can have on child development as well as the individual differences in severity of psychological outcomes. The objective of this pilot study was to identify possible explanations that could account for the CSA psychological outcome variability and give insights for further research. A sample of 25 Russian speaking girls by the decision of the person directing the proceedings were recognized as CSA victims and were assigned to psychological or complex psychiatric and psychological expert examination. During examination demographical data was collected and several self-report measures regarding peritraumatic and posttraumatic experiences were applied. Correlation analysis revealed that the only demographical characteristic associated with posttraumatic symptoms (familiarity with abuser, type of abuse, age at onset of abuse, time after last episode) was age at onset of abuse. Peritraumatic measures overall were associated with all of the posttraumatic symptoms and stepwise regression analysis showed that age at onset of abuse and peritraumatic experiences explained nearly $50 \%$ of variation of several posttraumatic symptoms. Further research directions are discussed.
\end{abstract}

\section{Introduction}

Depending on vagueness of CSA definitions, approximately $5 \%-50 \%$ people have suffered from it [1]. Latvian Protection of the Rights of the Child Law [2] states that "CSA is the involving of a child in sexual activities that the child does not understand or to which the child cannot knowingly give consent". Child involvement in sexual activities can result in various short and long-term psychological and psychiatric effects [3] which are not always severe enough for clinical diagnosis [4]. Contraintuitively, some authors mention that nearly $40 \%$ of CSA victims can be asymptomatic [5]. While majority of researchers tend to ignore asymptomatic victims and pay more attention to detected consequences, others try to explore differences between the two [6]. Recently factors affecting severity of CSA consequences have been analyzed in the framework of pretraumatic, peritraumatic and posttraumatic context [7] especially focusing on peritraumatic dissociation and peritraumatic distress [8].

Peritraumatic distress includes negative affect and arousal of sympathetic nervous system during trauma or shortly after [9]. Peritraumatic dissociation is experience of dissociative symptoms (mainly depersonalization and derealization) during trauma or shortly after [10]. Several studies have shown link between the two peritraumatic variables and severity of posttraumatic consequences [11-13]. Also, there are several crucial demographical and sexual abuse related risk factors that can influence psychological symptom severity [14] of whom victim age at onset of abuse, familiarity with abuser (known/unknown), type of sexual abuse (with/without physical contact) and time after last abuse (more/less than 6 months) will be included in current study.

The aim of the study was to practically explore previously made theoretical assumptions that peritraumatic factors (dissociation and distress) are linked with severity of posttraumatic consequences and could interplay with several demographical and abuse related variables. In order to achieve the goal, two research questions were made: (1) which of demographical and abuse related variables are associated with peritraumatic dissociation and distress and posttraumatic consequences? (2) When adjusting for demographical and abuse related variables, is peritraumatic distress and peritraumatic dissociation significantly related to posttraumatic symptoms? 


\section{Methods}

A sample of 25 Russian speaking girls aged 9-15 years $(\mathrm{M}=12,20, \mathrm{SD}=1,61)$ by the decision of the person directing the proceedings were recognized as CSA victims. Victim age at first episode of abuse ranged from 9-15 years $(\mathrm{M}=$ $11,40 ; \mathrm{SD}=1,57)$. All abusers were male aged $16-59$ years $(\mathrm{M}=38,44 ; \mathrm{SD}=12,73)-15$ were known to victim 10 were strangers. In 8 cases assessment was made less than 6 months after last abuse episode and 17 cases were assessed more than 6 months later. Also 9 children were victims of contact sexual abuse and 16 were abused without physical contact.

Measures applied in the study included: (1) Trauma symptom checklist for children (TSCC) [15] a 54 item posttraumatic symptom self-report. Each item is scored from 0 (never) to 3 (almost all of the time). TSCC contains 6 subscales: anxiety, depression, posttraumatic stress, sexual concerns, dissociation and anger. (2) Peritraumatic Dissociative Experiences Questionnaire (PDEQ) [10] is 10-item self-report scale measuring peritraumatic dissociation (e.g., depersonalization, derealization). Each item is scored from 0 (not at all true) to 4 (extremely true). Peritraumatic Distress Inventory (PDI) [9] is a 13-item self-report measuring pe-

Table 1. Descriptive statistics and internal consistency coefficients. I- TSCC average T values

\begin{tabular}{|l|l|l|l|l|}
\hline & $\begin{array}{c}\text { T } \\
\text { values }^{1}\end{array}$ & M & SD & $\boldsymbol{\alpha}$ \\
\hline Peritraumatic distress & & 16,43 & 8,58 & 0,79 \\
\hline Peritraumatic dissociation & & 17,78 & 7,08 & 0,84 \\
\hline Anxiety & 59 & 8,50 & 4,75 & 0,71 \\
\hline Depression & 56 & 8,29 & 5,62 & 0,84 \\
\hline Anger & 58 & 6,29 & 4,14 & 0,75 \\
\hline Posttraumatic stress & 68 & 9,67 & 5,48 & 0,82 \\
\hline Dissociation & 55 & 5,96 & 4,49 & 0,80 \\
\hline Sexual concerns & 50 & 3,46 & 3,82 & 0,75 \\
\hline
\end{tabular}

Table 2. Correlational matrix

Notes: TSCC subscales: Anx-anxiety, Dep-depression, Ang-anger, Pts-posttraumatic stress, Dis-dissociation, Sex-sexual concerns; PDiso-peritraumatic dissociation, PDist-peritraumatic distress; Age $1^{\text {st }}$ ep. - age at onset of abuse. $* *-p<0,01 ; *-p<0,05$

\begin{tabular}{|l|l|l|l|l|l|l|l|l|}
\hline & Anx & Dep & Ang & Pts & Dis & Sex & PDiso & PDist \\
\hline PDiso & 0,05 & $0,50^{* *}$ & 0,34 & $0,40^{*}$ & $0,65^{*}$ & 0,35 & 1 & \\
\hline PDist & $0,55^{* *}$ & $0,47^{*}$ & $0,67^{* *}$ & $0,53^{* *}$ & $0,49^{*}$ & $0,59^{* *}$ & $0,59^{* *}$ & 1 \\
\hline Age $1^{\text {st }}$ ep. & 0,26 & $0,47^{*}$ & 0,16 & 0,2 & $0,37^{*}$ & $0,65^{*}$ & 0,32 & 0,27 \\
\hline Familiarity & $-0,26$ & $-0,05$ & $-0,12$ & $-0,1$ & 0,01 & $-0,11$ & 0,12 & $-0,17$ \\
\hline Contact & 0,04 & 0,01 & $-0,06$ & $-0,2$ & $-0,07$ & 0,16 & $-0,2$ & 0,05 \\
\hline
\end{tabular}

ritraumatic distress (e.g., sadness, helplessness, sweating). Each item is scored from 0 (not at all true) to 4 (extremely true). Information about demographical and abuse related variables was obtained during semi-structured interview which included questions regarding familiarity with abuser, type of sexual abuse, time after last abuse etc.

Data were gathered during psychological or complex psychiatric and psychological expert examination. Procedure included semi-structured interview with the child, which was followed by the PDI, PDEQ and TSCC. Data analysis was made applying IBM SPSS Statistics version 20.

\section{Results}

Before correlational analysis, tests of normality were carried out using Kolmogorov-Smirnoff test with Liliefors correction [16] as a result normal distribution was violated in PDEQ $(\mathrm{D}=0,22, \mathrm{p}=0,01)$ and TSCC anger $(\mathrm{D}=0,21, \mathrm{p}$ $=0,02)$ and sexual concern $(\mathrm{D}=0,21, \mathrm{p}=0,02)$ subscales. Further analysis regarding scales mentioned above included nonparametric tests. Descriptive statistics and Cronbach alpha coefficients are displayed in Table 1. As can be seen from Table 1, internal consistency coefficients are appropriate for further statistical analysis. On average from all the TSCC scales only posttraumatic stress was significantly elevated $(T=68)$.

In order to answer (1) research question: which of demographical and abuse related variables are associated with peritraumatic dissociation and distress and posttraumatic consequences? Pearson, Spearmen and Point-Biserial correlation analysis was made (Table 1). It can be seen, that peritraumatic distress is significantly associated with peritraumatic dissociation and all TSCC subscales (anxiety, depression, anger, posttraumatic stress, dissociation, sexual concerns). Peritraumatic dissociation is associated with TSCC subscales - posttraumatic stress, depression and dissociation. From demographical and sexual abuse related variables significant correlations were found only between victim age at onset of abuse with depression, dissociation and sexual concern subscales. Taking into account that no other demographical or abuse related variable was significantly related to peritraumatic or posttraumatic symptoms, they were excluded from further analysis [17] and research questions.

In order to answer (2) research question: when adjusting for victim age at onset of abuse, is peritraumatic distress and peritraumatic dissociation significantly related to posttraumatic 
symptoms? Six separate stepwise regression analysis were carried out for each of TSCC subscale. At first step one of the TSCC subscales was entered as dependent variable and victim age at onset of abuse as independent variable. At second step peritraumatic distress and peritraumatic disociation were added as independent variables.

When anxiety was added at first step as dependent variable, there was no significant association with victim age at onset of abuse $F(1,20)=1,39, p=0,25$. After peritraumatic distress and dissociation were added at second step, they significantly improved associations with dependent variable $\left(\Delta R^{2}=0,35, p<0,05\right), F(2,17)=4,12, p=0,02$. Peritraumatic distress has a significant association in relation with anxiety $(\beta=0,73, p<0,01)$. Model altogether explains $42 \%$ of anxiety symptom variation. There was a significant association between depression and independent variable $\mathrm{F}(1,23)=5,46, \mathrm{p}=0,03$, but after peritraumatic distress and dissociation were added at second step, they did not significantly improve the model $\mathrm{F}(2,21)=4,48, \mathrm{p}=0,20)$. Altogether model explains $34 \%$ of depression symptom variation. Anger was not significantly associated with victim age at onset of abuse $F(1,23)=0,53, p=0,47$ and when peritraumatic distress and dissociation were added at second step, they did not significantly improve associations with dependent variable $F(2,21)=1,91, p=0,15$. When posttraumatic stress was added at first step as dependent variable, there was no significant association with independent variable $\mathrm{F}(1,23)=0,80, \mathrm{p}=0,39$, but after peritraumatic distress and dissociation were added at second step, they significantly improved associations with dependent variable $\left(\Delta \mathrm{R}^{2}=0,41\right.$, $\mathrm{p}<0,01), \mathrm{F}(2,21)=4,55, \mathrm{p}=0,02$. Peritraumatic distress has a significant association in relation with posttraumatic stress $(\beta=0,66, p=0,01)$. Model altogether explains $44 \%$ of posttraumatic stress symptom variation. At first step dissociation was not significantly associated with victim age at onset of abuse $F(1,23)=3,18, p=0,09$. After peritraumatic distress and dissociation were added at second step, they significantly improved associations with dependent variable $\left(\Delta \mathrm{R}^{2}=0,34\right.$, $\mathrm{p}<0,01), \mathrm{F}(2,21)=5,50, \mathrm{p}=0,07$. Peritraumatic dissociation has a significant association in relation with persistent dissociation $(\beta=0,48, p=0,04)$. Model altogether explains $47 \%$ of persistent dissociation symptom variation. Lastly, sexual concerns were significantly associated with independent variable $F(1,23)=14,23, p=0,01$. After peritraumatic distress and dissociation were added at second step, they did not significantly improve associations with dependent variable $\left(\Delta R^{2}=0,11, p<0,20\right)$. Victim age at onset of abuse has a significant value in relation with sexual concerns $(\beta$ $=0,57, p=0,05)$. Model altogether explains $53 \%$ of sexual concern variation.

\section{Discussion}

The aim of this study was to test theoretical assumptions that peritraumatic experience (distress and dissociation), demographical and sexual abuse related variables are associated with CSA symptom severity.

In order to identify correlations between demographical and abuse related variables, peritraumatic experiences (dissociation and distress) and posttraumatic consequences Pearson, Spearmen and Point-Biserial correlation analysis was made (Table 1). The only significant symptom association was between victim age at onset of abuse, which is in line with previous research conclusions [18] that older victims are more cognitively matured and can better understand meaning of sexual abuse which, for example, in turn can lead to negative attributional styles, rumination that can result in more severe depression symptoms [19]. Other variables - familiarity, type of contact, time after last abuse were not significantly associated with other measures and are contrary to recently conducted studies [7]. More likely that lack of associations is due to statistical limitations - small sample size, uneven subgroups [16], but this assumption should be tested in more homogenous and extended sample.

It was found, that adjusting for victim age at onset of abuse, peritraumatic distress and peritraumatic dissociation were significantly associated with anxiety, posttraumatic stress and dissociation. It is suggested elsewhere, that peritraumatic arousal of sympathetic nervous system intensifies emotionally charged experience storage in long term memory and feelings of fear [11]. It is called peritraumatic reactivity - a process during trauma that leads to hyperactivation of amygdala and other paralimbic structures on one hand and insufficient activation of prefrontal cortex on the other, which can lead, for example, to PTSS hyperarousal symptoms [20]. Peritraumatic reactivity possibly could account for relations found between peritraumatic distress and peritraumatic dissociation with anxiety and PTS symptoms. On the other hand peritraumatic distress and peritraumatic dissociation are related differently with persistent dissociation symptoms. Peritraumatic dissociation has similar neural basis with peritraumatic distress (autonomic nervous system), but contrary to peritraumatic distress when sympathetic nervous system is activated - parasympathetic nervous system takes over [21]. Some suggest, that peritraumatic dissociation reflects sudden, adaptive reaction to trauma (a defense mechanism against peritraumatic distress) which can transform to persistent dissociation [22]. Also it is hard to draw a line where peritraumatic dissociation ends and persistent dissociation begins, so it is plausible that the two will be related.

Several other findings include that peritraumatic distress and dissociation did not significantly improve regression 
model regarding depression symptoms, thus it can be speculated that depression symptoms are more dependent on posttrauma experience, for example, negative attributional styles, rumination etc. [19]. Peritraumatic experience (distress and dissociation) did not significantly improve regression model associated with sexual concerns, but victim age at onset of abuse had significant impact on associations with sexual concern symptoms, which can reflect that the older victims have more sexual knowledge, possibly, leading to engagement in sexual behavior [18]. Regression analysis did not show significant associations between anger and victim age at onset of abuse alone nor when peritraumatic distress and peritraumatic dissociation where added at second step. This could be due to fact that anger as posttraumatic consequences arises if the trauma is violent [23], but current sample had only 9 cases when there was sexual abuse with physical contact.

\section{Conclusion}

Peritraumatic distress is significantly associated with peritraumatic dissociation and all TSCC subscales (anxiety, depression, anger, posttraumatic stress, dissociation, sexual concerns). Peritraumatic dissociation is associated with TSCC subscales - posttraumatic stress, depression and dissociation. From demographical and sexual abuse related variables significant correlations were found only between victim age at onset of abuse with depression, dissociation and sexual concern subscales. Regression model including age at onset of abuse, peritraumatic dissociation and peritraumatic distress explains nearly $50 \%$ of variation of anxiety, PTS and persistent dissociation symptoms. These findings suggest that peritraumatic experience could be valuable in explaining individual posttraumatic differences and also could shed light on mechanisms of posttraumatic reaction formation including asymptomatic children. It should be noted, however, that current pilot study has significant limitations regarding statistical procedures (small sample size, small and heterogeneous subgroups) which restricts any generalization of current results. In overcoming limitations mentioned, future research should focus on larger and more homogenous samples. If similar research complements results above, then peritraumatic experience potentially could improve psychological and psychiatric expert examinations dealing with CSA consequence questions.

\section{References}

1. Haugaard JJ. The challenge of defining child sexual abuse. Am Psychol 2000; 55(9):1036-1039.

https://doi.org/10.1037/0003-066X.55.9.1036

2. Bērnu tiesību aizsardzības likums (Latvian Protection of the
Rights of the Child Law). Riga. 1998. Available from: https:// likumi.lv/doc.php?id=49096

3. Godbout N, Briere J, Sabourin S, Lussier, Y. Child sexual abuse and subsequent relational and personal functioning: the role of parental support. Child Abuse Negl 2014; 38(2):317-325. https://doi.org/10.1016/j.chiabu.2013.10.001

4. Bücker J, Kapczinski F, Post R., Ceresér K, Szobot C, Yatham L, Kapzinski NS, Kauer-Sant Anna M. Cognitive impairment in school-aged children with early trauma. Compr Psychiatry 2012; 53(6):758-764.

https://doi.org/10.1016/j.comppsych.2011.12.006

5. Finkelhor D, Berliner L. Research on the treatment of sexually abused children: a review and recommendations. J Am Acad Child Adolesc Psychiatry 1995; 34(11):1408-1423.

https://doi.org/10.1097/00004583-199511000-00007

6. Kendall-Tackett K, Williams L, Finkelhor D. Impact of sexual abuse on children: a review and synthesis of recent empirical studies. Psychol Bull 1993 113(1):164-180.

https://doi.org/10.1037/0033-2909.113.1.164

7. Trickey D, Siddaway A, Meiser-Stedman R, Serpell L, Field A. A meta-analysis of risk factors for post-traumatic stress disorder in children and adolescents. Clin Psychol Rev 2012; 32(2):122-138.

https://doi.org/10.1016/j.cpr.2011.12.001

8. Bui E, Joubert S, Manetti A, Camassel C, Charpentier S, Ribereau-Gayon R, Schmitt L, Aouizerate B, Brunet A, Birmes P, Arbus C. Peritraumatic distress predicts posttraumatic stress symptoms in older people. Int J Geriatr Psychiatry 2010; 25(12):1306-1310.

https://doi.org/10.1002/gps.2445

9. Brunet A, Weiss DS, Metzler TJ, Best SR, Neylan TC, Rogers C, Fagan J, Marmar CR. The peritraumatic distress inventory: a proposed measure of PTSD criterion A2.Am J Psychiatry 2001; 158(9):1480-1485.

https://doi.org/10.1176/appi.ajp.158.9.1480

10. Marmar CR, Weiss DS, Metzler TJ. The peritraumatic dissociative experiences questionnaire, in assessing psychological trauma and PTSD. New York. Guilford 1997.

11. Kuhn E, Blanchard E, Fuse T, Hickling E, Broderick J. Heart rate of motor vehicle accident survivors in the emergency department, peritraumatic psychological reactions, ASD, and PTSD severity: a 6-month prospective study. J Trauma Stress 2006; 19(5):735-740.

https://doi.org/10.1002/jts.20150

12. Kumpula M J, Orcutt O, Bardeen J, Varkovitzky LR. Peritraumatic dissociation and experiential avoidance as prospective predictors of posttraumatic stress symptoms. J Abnorm Psychol 2011; 120(3):617-627. https://doi.org/10.1037/a0023927

13. Nishi D, Matsuoka Y. Peritraumatic distress after an earthquake: a bridge between neuroimaging and epidemiology. Mol Psychiatry 2013; 18(7):743-744. 
https://doi.org/10.1038/mp.2012.94

14. Trickett P K, Noll J G, Putnam FW. The impact of sexual abuse on female development: lessons from a multigenerational, longitudinal research study. Dev. Psychopathol 2011; 23(2):453-476. https://doi.org/10.1017/S0954579411000174

15. Briere J. Trauma Symptom Checklist for Children: Professional Manual. Odessa. Psychological Assessment Resources, 1995.

16. Field AP. Discovering statistics using SPSS. London. Sage, 2009.

17. Leech NL, Barret KC, Morgan GA. SPSS for intermediate statistics: Use and interpretation. New York. L.Erlbaum Associates, 2008.

18. Nilsson D, Wadsby M, Svedin CG. The psychometric properties of trauma symptom checklist for children (TSCC) in a sample of Swedish children. Child Abuse Negl 2008; 32(6):627-636.

https://doi.org/10.1016/j.chiabu.2007.09.009

19. Bomyea J, Risbrough V, Lang A. A consideration of select pre-trauma factors as key vulnerabilities in PTSD. Clin Psychol Rev 32(7):630-641.

https://doi.org/10.1016/j.cpr.2012.06.008

20. Pitman RK, Shalev AY, Orr SP. Post-traumatic stress disorder: Emotion, conditioning, and memory. Cambridge MIT, 2000.

21. Briere J, Scott C, Weathers FW. Peritraumatic and persistent dissociation in the presumed etiology of PTSD. Am J Psychiatry 2005; 162: 2295-2301.

https://doi.org/10.1176/appi.ajp.162.12.2295

22. Otis C, Marchand A, Courtois F. Peritraumatic dissociation as a mediator of peritraumatic distress and PTSD: A retrospective, cross-sectional study. J Trauma Dissociation 2012; 13, 469-477. https://doi.org/10.1080/15299732.2012.670870

23. Kunst MJ, Winkel FW, Bogaerts S. Posttraumatic anger, re- called peritraumatic emotions, and PTSD in victims of violent crime. J Interpers Violence 2011; 26(17):3561-3579.

https://doi.org/10.1177/0886260511403753

\section{PERITRAUMATINIAI FAKTORIAI IR POSTRAUMATINIAI SIMPTOMAI VAIKU SEKSUALINĖS PRIEVARTOS ATVEJAIS \\ R. Eglītis, D. Landmane}

Raktažodžiai: seksualinè prievarta prieš vaikus, trauma, peritrauminis stresas, peritrauminè disociacija, postrauminès reakcijos.

Santrauka

Sveikatos ir teisès specialistai supranta vaikų seksualinės prievartos neigiamą poveikị vaiko vystymuisi bei individualius sunkių psichologinių pasekmių skirtumus. Šio bandomojo tyrimo tikslas buvo nustatyti galimus paaiškinimus, kurie galètų būti susiję su seksualinès prievartos psichologinio rezultato kintamumu ir pateikti ịžvalgas tolesniems tyrimams. Buvo atrinktos 25 rusakalbės merginos, kurios, vadovaujantis teismo sprendimu, buvo pripažintos seksualinės prievartos aukomis ir kurioms buvo priskirta psichologinè ar kompleksinè psichiatrinè ir psichologinė ekspertizè. Tyrimo metu buvo renkami demografiniai duomenys ir buvo taikyti keli savistabos klausimynai apie peritrauminę ir postraumatinę patirtị. Duomenų palyginamoji analizè parodè, kad vienintele demografinè charakteristika, susijusi su postrauminiais simptomais (prievartautojo pažinojimas, prievartos rūšis, amžius prievartos pradžioje, laikas nuo paskutinio epizodo) buvo aukos amžius, prasidejus prievartai. Bendri peritrauminiai rodikliai buvo susiję su visais postrauminiais simptomais, ir laipsniškos regresijos analizè parodè, kad aukos amžius, prasidèjus prievartai ir peritrauminé patirtis buvo susijusi su beveik $50 \%$ postrauminių simptomų variantų. Numatomos tolesnès šio tyrimo kryptys.

Adresas susirašinèti: egliitis.raitis@gmail.com

Gauta 2017-09-26 